\title{
KEPRIBADIAN, KOMUNIKASI, KELOMPOK TEMAN SEBAYA, IKLIM SEKOLAH DAN PERILAKU BULLYING
}

\author{
Irvan Usman \\ Fakultas Ilmu Pendidikan \\ Universitas Negeri Gorontalo \\ Jalan Jenderal Sudirman No. 6 Kota Gorontalo \\ irvanusman@yahoo.co.id
}

\begin{abstract}
Nowadays, bullying is common among students. Previous researches explored the causes and the effect of bullying among students. This research was aimed to explore the role of personality, communication, peer and school climate to bullying among senior high school students in Gorontalo. The subjects were 103 students. Data was collected through personality scale, communication scale, peer influence scale, school climate scale and bullying scale. This research was quantitative research with regression analysis. A research result shows that personality, communication, peer and school climate influence bullying among senior high school students in Gorontalo.
\end{abstract}

Keywords: bullying, communication, peer, personality, school climate

\begin{abstract}
Abstrak
Saat ini, perilaku bullying marak terjadi pada siswa di sekolah. Beberapa penelitian terdahulu berupaya mengetahui penyebab dan akibat perilaku bullying pada siswa. Tujuan penelitian ini adalah untuk mengetahui peranan kepribadian, komunikasi, kelompok teman sebaya dani klim sekolah terhadap perilaku bullying padasiswa SMA di Kota Gorontalo. Subjek penelitian ini adalah siswa-siswi dari tiga SMA di Kota Gorontalo yang berjumlah 103 siswa. Data dikumpulkan melalui beberapa skala yaitu skala kepribadian, skala komunikasi, skala pengaruh teman sebaya, dan skala perilaku bullying. Penelitian ini menggunakan pendekatan kuantitatif dan menggunakan teknikan alisis regresi untuk menguji hipotesis penelitian. Hasil penelitian menunjukkan bahwa ada pengaruh yang signifikan antara kepribadian, komunikasi interpersonal remaja dengan orang tua, peran
\end{abstract}


kelompok teman sebaya dan iklim sekolah terhadap perilaku bullying padasiswa SMA di kota Gorontalo.

Kata kunci: iklim sekolah, komunikasi, peran kelompok sebaya, perilaku bullying, tipe kepribadian

\section{Pendahuluan}

Maraknya kasus-kasus kekerasan yang terjadi pada anak-anak usia sekolah saat ini sangat memprihatinkan bagi pendidik dan orang tua. Sekolah yang seharusnya menjadi tempat bagi anak menimba ilmu serta membantu membentuk karakter pribadi yang positif ternyata malah menjadi tempat tumbuh suburnya praktek-praktek bullying, sehingga memberikan ketakutan bagi anak untuk memasukinya.

Penelitian Yayasan Sejiwa (2008) menyebutkan bahwa sebagian kecil guru (27,5\%) menganggap bullying merupakan perilaku normal dan sebagian besar guru (73\%) menganggap bullying sebagai perilaku yang membahayakn siswa. Hal tersebut tidak dapat dianggap normal karena siswa tidak dapat belajar apabila siswa berada dalam keadaan tertekan, terancam dan ada yang menindasnya setiap hari sehingga perilaku bullying tidak bisa dianggap normal atau biasa (Netto, 2007). Menurut Edwards (2006) perilaku bullying paling sering terjadi pada masa-masa sekolah menengah atas (SMA), dikarenakan pada masa ini remaja memiliki egosentrisme yang tinggi.

Berdasarkan hasil wawancara yang peneliti lakukan pada beberapa orang siswa SMA di kota Gorontalo, peneliti menemukan beberapa kasus bullying . Sebagian besar interviewee mengemukakan bahwa mereka pernah melihat dan menjadi pelaku bullying. Adapun bentuk-bentuk bullying yang pernah terjadi antara lain seperti menyuruh push up, membentak, memelototi, memalak, mengejek dan yang paling ekstrim adalah pemukulan.

Berdasarkan hasil wawancara dengan 10 siswa disimpulkan bahwa perilaku bullying yang terjadi pada beberapa sekolah SMA di kota Gorontalo merupakan tindakan yang dilakukan oleh kakak kelas kepada adik kelas. Hal ini menunjukkan bahwa senioritas masih menjadi sebuah fenomena yang terus terjadi di sekolah. Adanya ketimpangan atau ketidakseimbangan kekuatan baik fisik maupun mental menjadi penyebab terjadi perilaku bullying di sekolah. Di samping itu pula dari beberapa orang siswa melaporkan bahwa siswa yang melakukan perilaku bullying 
itu disebabkan adanya faktor balas dendam. Ketika para siswa masih berstatus junior di sekolah tersebut, para siswa mendapatkan perlakuan bullying dari kakak kelas sehingga ketika para siswa menjadi senior siswa ini memperlakukan hal yang sama kepada siswa-siswa junior.

Astuti (2008) mengemukakan bahwa senioritas sebagai salah satu perilaku bullying, seringkali justru diperluas oleh siswa sendiri sebagai kejadian yang bersifat laten. Senioritas dilanjutkan untuk hiburan, penyaluran dendam, iri hati, atau mencari popularitas, melanjutkan tradisi atau untuk menunjukkan kekuasaan. Perilaku ini diperparah dengan tidak jelasnya tindakan dari para guru dan pengurus sekolah. Sebagian guru cenderung "membiarkan", sementara sebagian yang lain melarangnya.

Beberapa faktor diyakini menjadi penyebab terjadinya perilaku bullying di sekolah, antara lain adalah faktor kepribadian, komunikasi interpersonal yang dibangun remaja dengan orangtuanya, peran kelompok teman sebaya dan iklim sekolah. Pertama adalah faktor kepribadian yang memberikan kontribusi besar pada siswa dalam melakukan perilaku bullying atau menjadi pelaku bullying. Menurut Benitez \& Justicia (2006) pelaku bullying cenderung memiliki sikap empati yang rendah, impulsif, dominan, dan tidak bersahabat. Adapun menurut Novianti (2008) bahwa salah satu faktor terbesar penyebab siswa melakukan bullying adalah temperamen yaitu sifat yang terbentuk dari respon emosional. Hal ini mengarah pada perkembangan tingkah laku personalitas dan sosial siswa. Siswa yang aktif dan impulsif lebih mungkin untuk berlaku bullying dibandingkan dengan yang pasif atau pemalu.

Kedua adalah faktor komunikasi interpersonal siswa dengan orangtuanya. Siswa remaja yang tumbuh dalam keluarga yang menerapkan pola komunikasi yang negatif seperti sarcasm akan cenderung meniru kebiasaan tersebut dalam kesehariannya. Kekerasan verbal yang dilakukan orangtua kepada anak akan menjadi contoh perilaku. Hal ini akan diperparah dengan kurangnya kehangatan kasih sayang dan tiadanya dukungan dan pengarahan terhadap remaja, membuat siswa remaja memiliki kesempatan untuk menjadi seorang pelaku bullying.

Ketiga adalah pengaruh kelompok teman sebaya memberikan pengaruh terhadap tumbuhnya perilaku bullying di sekolah. Menurut Benitez dan Justicia (2006) kelompok teman sebaya yang memiliki masalah di sekolah akan memberikan dampak yang negatif bagi sekolah seperti kekerasan, perilaku membolos, rendahnya sikap menghormati kepada sesama teman dan guru. Teman di lingkungan sekolah idealnya berperan sebagai "partner" siswa dalam proses pencapaian program-program pendidikan. Namun demikian, fakta dilapangan berdasarkan hasil wawancara yang 
peneliti lakukan pada siswa SMA di Kota Gorontalo mengungkapkan bahwa ada sebagian siswa yang melakukan perilaku bullying di sekolah disebabkan oleh dorongan teman-temannya.

Keempat adalah iklim sekolah juga memberikan pengaruh pada siswa untuk menjadi pelaku bullying. Menurut Setiawati (2008) kecenderungan pihak sekolah yang sering mengabaikan keberadaan bullying menjadikan para siswa sebagai pelaku bullying mendapatkan penguatan terhadap perilaku tersebut untuk melakukan intimidasi pada siswa yang lain. Menurut Novianti (2008) tingkat pengawasan di sekolah menentukan seberapa banyak dan seringnya terjadi peristiwa bullying. Sebagaimana rendahnya tingkat pengawasan di rumah, rendahnya pengawasan di sekolah berkaitan erat dengan berkembangnya perilaku bullying di kalangan siswa. Pentingnya pengawasan dilakukan terutama di tempat bermain dan lapangan, karena biasanya di kedua tempat tersebut perilaku bullying kerap dilakukan.

Perilaku bullying dan hubungan yang mempengaruhinya telah diuji keabsahannya dibeberapa negara dan ditemukan adanya faktor-faktor yang signifikan yang mempengaruhi perilaku bullying pada kesehatan psikologis dan perkembangan fisik (Roland, 2000). Kemungkinan para siswa menjadi pelaku bullying dipengaruhi oleh beberapa variabel. Beberapa studi telah mengidentifikasi variabel umum yang terdiri dari empat domain yaitu individual, hubungan keluarga, kelompok teman sebaya dan sekolah, yang mana berkontribusi pada siswa dalam berperilaku bullying.

Hasil penelitian yang dilakukan oleh Tani et al (2003) mengungkapkan bahwa faktor-faktor dalam kepribadian berkontribusi besar pada ciri khas perilaku anakanak dalam situasi bullying, di mana tingginya tingkat dari ketidakstabilan emosi dan rendahnya tingkat dari keramahtamahan berpengaruh pada pelaku bullying. Traittrait dalam kepribadian big five berimplikasi pada perilaku bullying siswa. Seperti contoh, berdasarkan laporan diri dari guru pada anak yang berusia antara usia 9-13 tahun menunjukkan bahwa dimensi bersepakat, ketelitian dan keterbukaan terhadap pengalaman mempunyai hubungan yang tinggi pada masalah-masalah perilaku anak diantaranya mengintimidasi orang lain dan mengajak berkelahi (Tani et al., 2003). Juga pada studi yang sama menunjukkan adanya hubungan yang positif antara masalahmasalah sosial seperti perasaan malu atau penolakan dan skala neuroticism pada anak yang berusia 9-13 tahun di Central Italia.

Beberapa peneliti telah menguji hubungan antara kepribadian dengan pelaku sekaligus korban bullying. Salah satu studi pada anak remaja di Florance berusia antara 10-16 tahun menunjukkan bahwa kecenderungan seseorang dalam melakukan perilaku bullying berhubungan dengan faktor kepribadian yang dikenal dengan nama 
psychoticism (Slee \& Rigby, 1993; Tani et al., 2004) yang meliputi perilaku impulsif, mengajak orang lain bermusuhan, dan sensitif dalam situasi sosial. Warden \& Mackinnon (2003) berdasarkan penelitiannya pada anak remaja berusia 11-15 tahun di West of Scotland mengungkapkan bahwa anak remaja yang populer memberikan sumbangan positif pada perilaku prososial sebesar $68 \%$, adapun remaja yang menjadi pelaku sekaligus korban bullying sering ditolak oleh teman sebayanya, sedangkan pelaku bullying memberikan sumbangan 78\% pada anak remaja di West Scotland. Selain sikap simpati yang telah disebutkan di atas, empati memiliki peranan yang penting dalam hubungannya dengan perilaku bullying. Empati merupakan kondisi ketika remaja dapat merasakan seperti yang dirasakan oleh orang lain (Sejiwa, 2008).

Studi hubungan antara empati dan perilaku agresif secara ekstensif telah dilakukan pada anak-anak dan remaja (Gini, et al., 2006). Baru-baru ini sebuah penelitian yang dilakukan oleh Gini et al (2006) pada 318 remaja sekolah menengah atas di North of Italia yang terdiri dari 142 perempuan dan 176 laki-laki menunjukkan bahwa pada laki-laki perilaku bullying secara signifikan berhubungan dengan rendahnya tingkatan dari respon empati.

Beberapa studi telah menunjukkan bahwa keluarga (orangtua) memainkan peranan yang penting pada anak yang melakukan tindakan bullying. Rigby (2005) pada penelitiannya pada siswa sekolah menengah pertama (200 siswa) dan siswa sekolah menengah atas (200 siswa) di Adelaide Region in South Australia mengungkapkan bahwa siswa cenderung melakukan perilaku bullying dibandingkan dengan siswi seperti menendang dan mengancam. Perilaku bullying tersebut disebabkan oleh adanya dukungan dari orangtua pada anak untuk melakukannya dan juga ditemukan bahwa siswa yang melakukan perilaku bullying berasal dari keluarga yang broken home.

Penelitian yang dilakukan oleh Thornberry tahun 1994 (Benitez \& Justicia, 2006) pada remaja berusia 12-17 tahun di Canada menunjukkan 38\% remaja yang berasal dari keluarga yang tidak melakukan kekerasan di dalam rumah kadang-kadang melakukan perilaku kekerasan. Persentase ini meningkat sebesar 60\% ketika Thornberry menemukan remaja yang melakukan perilaku kekerasan berasal dari keluarga yang sering melakukan kekerasan dalam rumah dan menerapkan komunikasi yang tertutup.

Penelitian yang dilakukan oleh Nation et al., (2007) pada 4386 siswa sekolah menengah pertama dan siswa sekolah menengah atas dari 151 SMP dan 92 SMA di Italia dan USA menemukan adanya hubungan antara perilaku bullying dengan tekanan dari teman sebaya. Siswa yang melakukan perilaku bullying disebabkan oleh tekanan dari teman sebaya agar dapat diterima dalam kelompoknya. 
Rubin, Bukowski, \& Parker (Rodkin et al., 2000) mengungkapkan hasil penelitian mereka pada siswa sekolah menengah atas di German tentang hubungan antar teman sebaya bahwa beberapa siswa yang tidak popular (ditolak oleh teman sebaya) memiliki perilaku agresi atau bullying yang tinggi, menarik diri dan menahan dimensi-dimensi internal dan eksternal yang ada pada diri mereka. Disamping itu siswa-siswa yang tidak popular ini selalu berubah-ubah persepsi diri mereka tentang kualitas hubungan interpersonal.

Perilaku bullying adalah masalah sosial dan lingkungan sekolah merupakan salah satu faktor atas terjadinya perilaku tersebut. Olweus (Woods \& Wolke, 2004) pertama kali berspekulasi bahwa perilaku bullying/agresif yang dilakukan oleh para siswa merupakan sebuah reaksi dari rasa frustasi dan kegagalan di sekolah. Hal ini didukung oleh sebuah hasil penelitian yang dilakukan oleh Salwina et al (2009) yang mengungkapkan bahwa ada hubungan yang signifikan antara rendahnya nilai prestasi belajar dengan perilaku bullying. Akan tetapi, sebuah penelitian pada siswa di Greater Stockholm tidak memberikan bukti bahwa perilaku bullying/agresif merupakan akibat dari nilai-nilai yang buruk di sekolah.

Dari uraian pengaruh kepribadian, komunikasi interpersonal remaja dengan orangtua, peran kelompok teman sebaya dan iklim sekolah terhadap perilaku bullying, diasumsikan bahwa kepribadian, komunikasi interpersonal remaja dengan orangtua, peran kelompok teman sebaya dan iklim sekolah merupakan prediktor bagi perilaku bullying.

\section{Metode Penelitian}

Subjek penelitian ini adalah siswa-siswi Sekolah Menengah Atas di Kota Gorontalo yang terdiri dari tiga sekolah menengah atas, berjumlah 103 siswa. Karakteristik subjek penelitian adalah laki-laki dan perempuan yang duduk di kelas II jurusan ilmu pengetahuan alam dan ilmu pengetahuan sosial dan pernah melakukan bullying. Berdasarkan hasil wawancara peneliti dengan beberapa orang siswa SMA di kota Gorontalo menunjukkan bahwa ketiga sekolah tersebut terdapat kasus bullying diantara siswanya. Peneliti menggunakan siswa kelas II sebagai subyek penelitian karena memiliki perilaku bullying terhadap adik kelasnya. Adapun siswa kelas I cenderung menjadi korban bullying. Pada penelitian kali ini peneliti akan menggunakan teknik sampling yaitu purpossive sampling.

Prosedur pengumpulan data pada penelitian ini dilakukan dengan metode skala yaitu menggunakan butir-butir pengukur konstruk atau variabel yang digunakan dalam penelitian. Penyebaran dan pengumpulan data dilakukan secara langsung dengan 
meminta kesediaan subjek untuk mengisi. Untuk mendapatkan data, alat ukur yang digunakan dalam penelitian ini adalah skala perilaku bullying, skala kepribadian big five, skala komunikasi remaja dengan orangtua, skala peran kelompok teman sebaya dan skala iklim sekolah. Sebelum digunakan semua alat ukur penelitian di atas diuji coba untuk didapatkan koefisien reliabilitasnya. Sedangkan metode uji validitas yang digunakan dalam penelitian ini adalah teknik validitas isi melalui analisis rasional. Tabel 1 di bawah ini menjelaskan hasil reliabilitas alat ukur dalam penelitian ini.

Tabel 1

Reliabilitas alat ukur penelitian

\begin{tabular}{lc}
\hline Skala penelitian & Cronbach alpha \\
\hline Kepribadian Big Five & $0,887$. \\
Komunikasi remaja & $0,960$. \\
Pengaruh kelompok sebaya & $0,922$. \\
Iklim sekolah & $0,901$. \\
Perilaku bullying & .920. \\
\hline
\end{tabular}

Berdasarkan hasil pengujian reliabilitas melalui teknik konsistensi internal didapatkan hasil koefisien Cronbach alpha yang memuaskan, yaitu di atas 0.80 . Hal ini menunjukkan bahwa koefisien reliabilitas alpha semua alat ukur yang digunakan dalam penelitian ini termasuk dalam ketegori tinggi (Azwar, 2009).

\section{Hasil dan Pembahasan}

Hasil analisis regresi dapat ditunjukkan pada tabel berikut:

Tabel 2

Hasil analisis Korelasi Berganda

\begin{tabular}{llr}
\hline & \multicolumn{2}{c}{ Perilaku bullying } \\
\cline { 2 - 3 } Variabel & $\beta$ & p value \\
\hline Kepribadian & .484 & $.000^{* *}$ \\
Komunikasi interpersonal & .257 & $.000^{* *}$ \\
remaja dengan orangtua & & \\
Peran kelompok teman sebaya & -.123 & $.045^{*}$ \\
Iklim sekolah & .405 & $.000^{* *}$ \\
$\mathrm{R}$ & & .360 \\
$\mathrm{~F}$ & & 13.785 \\
\hline $\mathrm{N}=103 .{ }^{*} \mathrm{p}<.05 . * * \mathrm{p}<.01$ & & \\
\end{tabular}


Berdasarkan Tabel 2 di atas, dapat diketahui bahwa hasil uji F statistik sebesar 13,785 dan ( $\mathrm{p}<0,05)$. Dengan demikian koefisien korelasi antara kepribadian, komunikasi interpersonal remaja dengan orangtua, peran kelompok teman sebaya dan iklim sekolah secara bersama-sama dengan perilaku bullying terdapat pengaruh yang signifikan. Adapun besarnya koefisien determinasi R Square $=0,360$ menunjukkan bahwa perilaku bullying siswa 36\% dapat dijelaskan oleh keempat variabel independen tersebut dan sisanya sebesar $64 \%$ dijelaskan oleh variabel lain yang tidak dimasukkan dalam model penelitian.

Berdasarkan data hasil penghitungan uji signifikansi korelasi ganda diperoleh F statistik sebesar 13,785 dan ( $\mathrm{p}<0,05)$, maka dapat ditarik kesimpulan bahwa koefisien korelasi antara kepribadian, komunikasi interpersonal remaja dengan orangtua, peran kelompok teman sebaya dan iklim sekolah secara bersama-sama dengan perilaku bullying terdapat pengaruh yang signifikan, sehingga hipotesis 1 dapat diterima. Adapun variabel kepribadian, komunikasi interpersonal remaja dengan orangtua, peran kelompok teman sebaya dan iklim sekolah secara parsial berpengaruh negatif yang signifikan dengan perilaku bullying. Dengan demikian hipotesis 2, 3, 4 dan 5 dapat diterima.

Pada variabel kepribadian ditemukan ada pengaruh negatif yang signifikan antara kepribadian dengan perilaku bullying. Semakin tinggi kepribadian seorang siswa, maka semakin rendah perilaku bullying siswa dan sebaliknya semakin rendah kepribadian, maka semakin tinggi perilaku bullying pada diri siswa. Hasil analisis kepribadian per aspek di atas juga menunjukkan bahwa kelima aspek kepribadian berpengaruh negatif yang signifikan terhadap perilaku bullying pada siswa. Hal ini senada dengan ungkapan dari Tani et al., (2003) bahwa siswa yang memiliki stabilitas emosi yang tinggi dan memiliki keramahtamahan akan menyebabkan siswa tidak berperilaku bullying di sekolah.

Hasil penelitian ini juga menunjukkan bahwa dimensi bersepakat, keterbukaan terhadap pengalaman dan ketelitian memiliki pengaruh yang negatif dan signifikan terhadap perilaku bullying pada siswa. Hal ini menunjukkan tingginya skor siswa dalam dimensi-dimensi tersebut. Senada dengan hasil di atas, Raad dan Perugini (2002) mengungkapkan bahwa siswa yang memiliki dimensi kepribadian bersepakat yang tinggi cenderung untuk menggalang hubungan yang baik dengan orang lain dan senang menjalin kerjasama yang baik dengan orang lain. Pada dimensi keterbukaan terhadap pengalaman juga menunjukkan adanya pengaruh yang negatif dan signifikan terhadap perilaku bullying pada siswa. Hal ini menunjukkan kecenderungan siswa memilki intelektualitas yang tinggi dan terbuka akan hal-hal yang baru. Menurut 
Bettencourt et al., (2006) siswa-siswa yang memiliki performansi akademik yang baik di sekolahnya cenderung tidak melakukan perilaku bullying, sebaliknya siswasiswa yang memiliki masalah dalam performansi akademiknya cenderung akan melakukan perilaku bullying di sekolahnya.

Dimensi ketelitian juga memiliki hasil yang sama dengan dimensi-dimensi yang lain pada penelitian ini yaitu memiliki pengaruh yang negatif dan signifikan terhadap perilaku bullying siswa. Hal ini menunjukkan bahwa siswa memiliki disiplin diri yang baik dan memiliki tanggung jawab yang tinggi atas apa yang dilakukannya. Hasil penelitian yang dilakukan oleh Tani et al., (2003) juga menunjukkan hal yang sama dengan penelitian kali ini bahwa dimensi ketelitian berhubungan negatif dengan perilaku bullying pada siswa.

Hasil penelitian menemukan bahwa komunikasi interpersonal remaja dengan orangtua terbukti berpengaruh negatif terhadap perilaku bullying pada siswa SMA di kota Gorontalo. Hal ini menunjukkan bahwa komunikasi interpersonal yang dibangun oleh para siswa dengan orangtuanya sangat baik sehingga perilaku bullying yang ditimbulkannya juga rendah. Senada denga hal di atas, Smokowski dan Kopasz (2005) mengungkapkan bahwa orangtua yang menerapkan komunikasi yang terbuka, selalu melibatkan anak-anaknya dalam setiap kegiatan yang dilakukan oleh keluarga, dan menerapkan disiplin secara konsisten akan menghindarkan anak-anaknya dari perilaku bullying di sekolah.

Komunikasi antara remaja dengan orangtua adalah komunikasi yang terjadi diantara orangtua dengan anak-anaknya dalam berbagai hal sebagai sarana bertukar pikiran, mensosialisasikan nilai-nilai kepribadian orangtua kepada anaknya, dan penyampaian segala persoalan atau keluh kesah dari anak kepada kedua orang tuanya. Menurut Wong (2004) bahwa kualitas hubungan dan komunikasi interpersonal anak remaja dengan orangtuanya akan sangat mempengaruhi kehidupan remaja tersebut di masa yang akan datang. Semakin baik komunikasi yang dibangun antara orangtua dan remaja maka akan semakin menghindarkan remaja dari perilaku bullying. Anak remaja yang melakukan perilaku bullying di sekolah biasanya berasal dari keluarga yang sangat rendah perhatiannya dan membangun komunikasi yang tertutup.

Berdasarkan kategorisasi skor siswa yang telah di sebutkan di atas juga menunjukkan bahwa komunikasi interpersonal siswa dengan orangtuanya berada pada kategori tinggi sebesar 56\%. Hal ini menunjukkan bahwa siswa SMA di kota Gorontalo mampu membangun komunikasi yang baik dengan orangtuanya.

Hasil penelitian menemukan bahwa peran kelompok teman sebaya terbukti berpengaruh negatif terhadap perilaku bullying pada siswa SMA di kota Gorontalo. 
Hasil penelitian ini sesuai dengan hasil penelitian Nation et al., (2007) yang menemukan bahwa perilaku bullying disebabkan oleh tekanan dari teman sebaya agar dapat diterima dalam kelompoknya. Kelompok teman sebaya adalah sekelompok teman yang mempunyai ikatan emosional yang kuat dan siswa dapat berinteraksi, bergaul, bertukar pikiran, dan pengalaman dalam memberikan perubahan dan pengembangan dalam kehidupan sosial dan pribadinya.

Berdasarkan kategorisasi skor siswa tentang peran kelompok teman sebaya menunjukkan bahwa peran kelompok teman sebaya berada pada kategori tinggi sebesar 35\% dan sangat tinggi sebesar 36,9\%. Hal ini menunjukkan bahwa tekanan dari kelompok teman sebaya pada siswa untuk melakukan perilaku bullying sangat rendah. Senada dengan hal tersebut, Eisenberg dan Aalsma (2005) mengungkapkan bahwa siswa SMA tidak tergantung lagi pada tekanan-tekan ataupun keputusankeputusan dari teman sebayanya untuk melakukan perilaku bullying, karena pada masa SMA ini siswa sudah mampu berpikir secara objektif tentang apa yang harus dilakukannya dan meningkatnya nilai-nilai moralitas dalam dirinya.

Hasil penelitian menemukan bahwa iklim sekolah berpengaruh negatif dan signifikan terhadap perilaku bullying pada siswa se kota Gorontalo. Hasil penelitian ini sesuai dengan pernyataan dari Berger et al., (2008) yang mengungkapkan bahwa iklim sekolah yang dibangun dengan baik yaitu dengan menumbuhkan sikap toleransi yang tinggi antara guru, pimpinan sekolah, staf dan para siswa maka akan meminimalisir tumbuh dan berkembangnya perilaku bullying pada siswa.

Berdasarkan kategorisasi skor siswa tentang iklim sekolahnya menunjukkan bahwa iklim sekolah berada pada kategori tinggi atau sebesar $49.5 \%$ dan sangat tinggi atau sebesar $26.2 \%$. Hal ini menunjukkan bahwa iklim sekolah yang dibangun di sekolah tempat siswa belajar sangat baik sehingga kemungkinan siswa untuk melakukan perilaku bullying sangat rendah. Senada dengan hasil tersebut, Bauman dan Del Rio (2005) mengungkapkan bahwa iklim sekolah yang dibangun dengan baik, di mana terdapat komunikasi yang efektif antara pimpinan sekolah, guru, staf dan para siswa serta terciptanya sekolah yang aman dan nyaman akan mereduksi dan meminimalisir terjadinya perilaku bullying di antara para siswa.

\section{Simpulan}

Berdasarkan hasil penelitian maka diperoleh kesimpulan bahwa ada pengaruh negatif yang signifikan antara kepribadian, komunikasi interpersonal remaja dengan orang tua, peran kelompok teman sebaya dan iklim sekolah terhadap perilaku bullying pada siswa SMA di kota Gorontalo. Semakin stabil dan baik kepribadian siswa, semakin 
baik komunikasi interpersonal yang dibangun remaja dengan orangtuanya, semakin besar peran kelompok teman sebaya untuk mengajak temannya dalam menerapkan norma-norma positif yang ada dalam mayarakat serta semakin kondusif iklim di sekolah maka semakin rendah perilaku bullying pada siswa SMA di Kota Gorontalo.

\section{Daftar Pustaka}

Astuti, P.R. (2008). Meredam bullying. 3 cara efektifmengatasi kekerasan pada anak. Gramedia Widiaswara Indonesia: Jakarta

Azwar, S. (2009). Reliabilitas dan validitas. Pustaka Pelajar: Yogyakarta.

Benitez, J. L., \& Justicia, F. (2006). Bullying: Description and analysis of the phenomenon. Electronic Journal of Research in Educational of Psychology, 4 (9), 151-170.

Berger, C., Karimpour, R., \& Rodkin, P. C. (2008). Bullies and victims at school: perspectives and strategies for primary prevention. In T. Miller (ed). School violence and primary prevention. (pp: 287-314). Springer-Verleg: New York.

Bettencourt, B. A., Talley, A., \& Benjamin, A. J. (2006). Personality and aggressive behavior under provoking and neutral conditions: A meta analytic review. Journal of Psychological Bulletin, 132(5), 751-777.

Chapell, M. S., Hasselman, S. L., Kitchin, T., Lomon, S.N., MacIver, K.W., \& Sarullo, P.L. (2005). Bullying in elementary school, high school, and college. Journal of Adolescence, 41(164), 633-648.

Edwards, D.C. (2006). Ketika anak sulit diatur: Panduan bagi orang tua untuk mengubah masalah perilaku anak. Kaifa: Bandung.

Eisenberg, M.E \& Aalsma, M.C. (2005). Bullying and peer victimization: Position paper of the society for adolescent medicine. Journal of Adolescent Health, 36, 88-91.

Frisen, AA., Jonsson, A.K., \& Altoe, G. (2006). Does emphaty predict adolescents' bullying and defending behavior?. This is Preprint of an Article Accepted for Publication in Aggressive Behavior.

Gini, G., Albiero, P., Bonelli, B., \& Altoe, G. (2006). Does empathy predict adolescents' bullying and defending behavior?. This is Preprint of an Article Accepted For Publication in Aggressive Behavior. 
Holt, M. K., \& Espelage, D.L. (2007). Perceived social support among bullies, victims, and bully-victims. Journal of Youth Adolescence, 36, 984-994.

Nation, M., Vieno, A., Perkins, D. D., \& Santinello, M. (2007). Bullying in school and adolescent sense of empowerment: An analysis of relationship with parents, friends, and teachers. Journal of Community \& Applied Social Psychology, 10(3),115-127.

Netto, G. (2007). Bullying Di Sekolah. Diakses dari http://genenetto.blogspot.com/ 2007/05/bullying-di-sekolah.html.

Novianti, I. (2008). Fenomena kekerasan di lingkungan pendidikan. Jurnal Insania, 13(2), 1-10.

Raad, B.D., \& Perugini, M. (2002). Big five assessment. Hogrefe \& Huber Publisher: Germany.

Rodkin, P.C., Farmer, T.W., Pearl, R and Acker, R.V. (2000). Heterogeneity of popular boys: Antisocial and prosocial configurations. Journal of Developmental Psychology, 36(1), 14-24.

Roland, E. (2000). Bullying in school: Three national innovations in Norwegian school in 5 years. Journal of Aggressive Behavior, 26, 135-143. 